\title{
Experience of the nursing team concerning the care of patients with meningitis attended in emergency department
}

\author{
Rhenan G. Moura ${ }^{1}$, Cristina da S. Fernandes*1, Maria G.S.A. Brandão², Nelson M. Galindo Neto ${ }^{3}$, Joselany Á. \\ Caetano $^{4}$, Lívia M. Barros ${ }^{2}$ \\ ${ }^{1}$ University of Vale do Acaraú State, Sobral, Ceará, Brazil \\ ${ }^{2}$ University of International Integration of Afro-Brazilian Lusophony, Redemption, Ceará, Brazil \\ ${ }^{3}$ Federal Institute of Education, Science and Technology of Pernambuco, Pesqueira, Pernambuco, Brazil \\ ${ }^{4}$ University of Ceará, Fortaleza, Ceará, Brazil
}

Received: November 27, 2019

DOI: $10.5430 /$ jnep.v10n9p28
Accepted: March 4, 2020

URL: https://doi.org/10.5430/jnep.v10n9p28

\begin{abstract}
Objective: To unveil the experience of the nursing team in relation to the care of patients with meningitis attended in emergency departments.

Methods: Exploratory and qualitative study made with 13 nurses and 12 nursing technicians from the emergency sector of a public hospital located in Northeast of Brazil. The data was gathered through an interview using a semi-structured script. The interviews were transcribed, processed in the Iramuteq software and analyzed with the descending hierarchical classification.

Results: Three categories were obtained and they were referent to the accomplished interventions (administration of medication, patient's isolation, contribution in the accomplishment of exams, use of individual protection equipment and humanization), to the experienced feelings (fear and unsafety) and the disease's suggestive alerts (headache, neck stiffness, changes in the conscience level and vomit).

Conclusions: The nursing experience in the care of patients with meningitis, in the emergency sector, was shown to be permeated by the accomplishment of interventions, feelings, and knowledge about the symptoms.
\end{abstract}

Key Words: Nursing, Emergencies, Meningitis, Qualitative research

\section{INTRODUCTION}

Meningitis is a disease whose morbi-mortality remains high, especially in third world countries. It is estimated that each year, more than 1.2 million cases of bacterial meningitis occur all over the world. ${ }^{[1]}$ Currently, despite the advances of diagnostic and therapeutic studies, the disease remains a problem of public health, causing 241,000 deaths per year in the world. ${ }^{[2]}$

The meningitis' infection is considered as a problem of public health in many countries from Latin America, ${ }^{[3]}$ associated with the time of hospitalization, physical aftereffects, and deaths, as well as a higher suffering for the patient and his relative. ${ }^{[4]}$ In accordance with the National Administrative Department of Statistics (DANE), from Colombia, in

\footnotetext{
*Correspondence: Cristina da Silva Fernandes; Email: cardeal@decom.cefetmg.br; Address: Health Sciences Center, Vale do Acaraú State University, Sobral, Ceará, Brazil.
} 
2012, 288 deaths by meningitis were registered.

In Brazil, meningitis is considered an endemic disease with the occurrence of sporadic outbreaks in specific cities. In Brazilian territory, in 2017, 1,138 cases of meningitis were identified and, from these, 266 ended in death. In 2018, there was an incidence of 1,072 cases and 218 deaths. ${ }^{[1]}$ In the state of Ceará-Brazil, in 2017, there were 382 confirmed cases of meningitis. ${ }^{[5]}$

Meningitis is caused by the infectious process in the meninges, whose etiological cause may be bacterial, viral, fungal and parasitic. The early recognition of the pathology's signs and symptoms, such as acute pain, changes in the mental state, nausea and vomits, still in the disease's first hours and the early handling are vital to achieve the qualified assistance, because the therapeutics' early beginning may decrease the morbi-mortality, which will reflect in the improvement of the patient's prognostic and the reduction of complications. ${ }^{[6]}$

However, even when there is an early diagnostic of the disease and the beginning of the adequate treatment, it is estimated that $5 \%$ to $10 \%$ of the patients do not manage to survive and die between 24 to 48 hours after the first symptoms' appearance.The scientific literature points out that factors such as: age, severity, causal agent, duration of the disease during its acute presentation, baseline conditions of the patient and delay in starting effective antimicrobial therapy, increase the risk of death or development of complications. ${ }^{[7]}$ Furthermore, if there is no treatment, the death rate may result in $50 \%$ of the cases (CEARA, 2018).

In this context, when the patients shows meningitis' suggestive symptomatology, he tends to seek aid in emergency services, whose role is highlighted inside the hospital care because it is considered as a complex and critical environment, concerning the need to quickly, receive and treat, patients that shows imminent risk of death. Therefore, immediate care is needed, offered by a team that needs to be prepared for several urgency or emergency situations. ${ }^{[8]}$

Due to the emergency fact be the hospital's gateway, professionals from this service are, frequently, the first to deal with patients in meningitis' exacerbation stage, among them, the nursing team. ${ }^{[9,10]}$ The nurse develops a relevant contribution to the immediate recognition of signs and symptoms and in the quick accomplishment of appropriate interventions. ${ }^{[11-13]}$

In the emergency department, the nurses are the first professionals to get in contact with patients with meningitis, because they are the care's frontline, inclusive in reception and risk classification. In addition to this, the nurses are responsible for the care management and the leadership of nursing technicians, from the accomplishment of tasks that involves assistance and managerial activities. ${ }^{[10]}$

Qualitative study carried out in isolation wards in care units for patients with an infectious-contagious disease pointed out that the nursing team assumes a prominent role in this scenario, because, in addition to having to deal with their own fears and anxieties, in view of the risk acquiring communicable diseases, you need deal with new anxieties, reactions and needs special care for other patients admitted to the environment. ${ }^{[11]}$

In front of the considerations, the following questioning arises: What is the experience of the nursing team concerning the care for adult patients with meningitis attended in emergency department?

To answer this question, it is needed to unveil the subjectivity inherent to the care process of adult patients with meningitis in the emergency sector. Therefore, subjective aspects, such as feelings/experiences, involved in the nursing experience, once known, may contribute with the theme's state of the art so that the guidance of the managers and coordinators" decision-making not only occur based in quantitative and epidemiologic aspects but also subsidized by subjective questions that must be considered.

This way, the study aimed to unveil the experience of the nursing team concerning the care to adult patients with meningitis attended in the emergency departments.

\section{METHOD}

It is about an exploratory and qualitative study, accomplished in the months of May to July 2018 in the emergency sector from a reference hospital located in Northeast of Brazil (State of Ceará). The referred institution is a part of SUS and is also a reference in traumatic and clinical injuries, therefore, it can be considered as a high complexity facility to where the patients in the region are directed to.

The study's population was composed by the emergency's nursing team (15 nurses and 71 nursing technicians). The inclusion conditions were: to have a professional bond as a nurse or nursing technician with the hospital, compose the emergency sector's team for more than three months (time that the professional could amplify its experience in the care to patients with meningitis). The exclusion conditions were: to occupy only a position of management and/or administrative attributions and be detached due to vacations or license in the period of data gathering.

The data saturation criterion was used to determine the sample's quantitative. Therefore, the interviews were made until the moment where there was no theme or new con- 
tent/information concerning the studied phenomenon. ${ }^{[14]}$ This way, the sample was composed of 13 nurses and 12 nursing technicians.

The data was collected from the interview, which was prescheduled with the service's coordination. The nurses and nursing technicians were approached in accordance with the duty scales' order, in their work shift, accordingly with their available time, in a reserved department from the hospital that only the researcher and interviewed could go in. Each interview lasted, approximately, 25 minutes and was preceded by the reading and signature of the term of consent.

A semi-structured instrument was used and divided in two parts: the first with the identification data (gender, age, professional category) and the second with the following guiding question to be answered by the participants:" Tell me about your experience during the care, in emergency departments, of adult patients with a suspicion or confirmation of meningitis".

The participants' speeches were recorded and, subsequently, transcribed. For the data processing, one used the Interface software: R pourles Analyses Multidimensionnelles de Textes et de Questionnaires (IRaMuTeQ) 0.7 Alfa 2.3.3.1. From the anchoring to the R software, it accomplished the fragmentation of the text in segments and I can analyze it with basis lexicography or more robust, multivariate analysis. In this context, the multivariate analysis was chosen, by the Descendent Hierarchical Classification (DHC). Using this classification, the segments are grouped using the Chi-Square test in Classes, that are visually represented by IRaMuTeQ in a dendrogram. ${ }^{[15]}$

One highlights that data processing was compatible with the IRaMuTeQ, since the transcribed text was composed of 204 segments that had a processing harnessing of 82.35

In observance to Helsinki declaration, that regulates the research in human beings, the data's confidential nature and the anonymity of the involved were respected. The identification of the study's subjects was represented by the letter " $E$ " for nurses or "TE" for nursing technicians, followed by a crescent numerical sequence that corresponds to the sequence of interviews.

The research was approved by the Committee of ethic in Research from Universidade Estadual Vale do Acaraú, under report $\mathrm{n}^{\circ} 2.578 .328 / 2018$, and all participants signed the term of consent.

\section{RESULTS}

Among the participants, the following characteristics prevailed: $70.8 \%$ were male $(n=16)$, divided by the following form: $69.2 \%(n=9)$ of the nurses and $58.3 \%(n=7)$ of the nursing technicians. Concerning the age group, the nurses varied between 27 to 40 years old, meanwhile, the nursing technicians show an age group from 25 to 50 years old.

About the nurses' education level, 77\% $(n=10)$ had specialization in urgency and emergency, one had a master's degree, meanwhile, the rest of the group, $23 \%$ (3) only had the graduation. Regarding the time of professional formation, the variation went from 2 to 10 years of experience for nurses and from 4 to 29 years for the technicians.

The software IRaMuTeQ elaborated the dendrogram (see Figure 1), with the words' division in three classes: Nursing interventions in the care for patients with meningitis; Feelings associated with the care of patients with meningitis; Alert signs for the diagnostic of Meningitis during the emergency care.

\subsection{Class I: Nursing Intervention in the care of patients with meningitis}

The first class refers to the nursing interventions, expressed in the professionals' speeches. In this class, which corresponds to $29.2 \%$ of the corpus, it was possible to observe the recurrence of speeches related to the form that the nursing acts towards the patient with meningitis.

Nursing interventions referred to the patient's isolation and the administration of medication were highlighted in the professionals' speeches.

In these cases, it is needed to offer care and isolate the patient. (E2)

We need to administrate the medication, accordingly with the medical prescription, to keep them in isolation, offer comfort and observe the alert signs of the clinical picture. (E5)

It is common to put him in an isolated environment from the rest of the patients, we need to avoid unprotected contact, however, we also need to give care and the adequate attention to the patient. (TE12)

It was also highlighted that the experience of the nursing professional is permeated by its contribution to accomplish laboratory and image exams, needed for the quick diagnostic of meningitis, in the emergency sector. Although these exams are not made directly by the nurse, his contribution to the organization, provision of material and the starting of laboratory services are needed to enable the exams' accomplishment. 


\begin{tabular}{|c|c|c|c|c|c|c|c|c|}
\hline \multicolumn{9}{|c|}{$\begin{array}{l}\text { EXPERIENCE OF THE NURSING TEA } \\
\text { EMERGENCY DEPARTMENTS }\end{array}$} \\
\hline & & & & & & & & \\
\hline \multirow{2}{*}{\multicolumn{3}{|c|}{$\begin{array}{l}\text { CLASS 1: } 29.2 \% \\
\text { Nursing interventions in the care of } \\
\text { patients with meningitis }\end{array}$}} & & & & & & \\
\hline & & & \multicolumn{3}{|c|}{$\begin{array}{l}\text { CLASS 2: } 32.1 \% \\
\text { Training need for the care of patients } \\
\text { with meningitis }\end{array}$} & \multicolumn{3}{|c|}{$\begin{array}{l}\text { CLASS 3: } 38.7 \% \\
\text { Pathophysiology, signs and } \\
\text { symptoms for the diagnostic of } \\
\text { meningitis during the nursing care }\end{array}$} \\
\hline WORDS & $\mathrm{X}^{2}$ & $\mathrm{P}$ & WORDS & $\mathrm{X}^{2}$ & $P$ & WORDS & $\mathrm{X}^{2}$ & $P$ \\
\hline Isolation & 50.71 & $<0.0001$ & Fear & 20.08 & $<0.0001$ & Nape & 46.54 & $<0.0001$ \\
\hline IPE's & 50.71 & $<0.0001$ & No & 19.12 & $<0.0001$ & Fever & 46.54 & $<0.0001$ \\
\hline To use & 37.15 & $<0.0001$ & Capacitation & 17.73 & $<0.0001$ & Stiffness & 38.03 & $<0.0001$ \\
\hline Prescription & 25.82 & $<0.0001$ & To have & 14.81 & 0.00011 & Headache & 38.03 & $<0.0001$ \\
\hline To isolate & 25.82 & $<0.0001$ & Good & 13.14 & 0.00028 & Pain & 28.02 & $<0.0001$ \\
\hline Patient & 25.8 & $<0.0001$ & Training & 13.14 & 0.00028 & Inflammation & 24.2 & $<0.0001$ \\
\hline Care & 17.74 & $<0.0001$ & Glove & 10.88 & 0.00097 & Vomit & 22.6 & $<0.0001$ \\
\hline To keep & 17.74 & $<0.0001$ & Concern & 10.88 & 0.00097 & Being & 18.14 & $<0.0001$ \\
\hline To administrate & 15.11 & 0.00010 & Prognostic & 10.88 & 0.00097 & Meninge & 16.85 & $<0.0001$ \\
\hline Administration & 15.11 & 0.00010 & Reason & 10.88 & 0.00097 & Bacterial & 15.07 & 0.00010 \\
\hline Medication & 13.84 & 0.00019 & To evolve & 10.88 & 0.00097 & Intense & 15.07 & 0.00010 \\
\hline $\begin{array}{l}\text { To } \\
\text { communicate }\end{array}$ & 12.52 & 0.00040 & Alone & 9.61 & 0.00193 & Head & 15.07 & 0.00010 \\
\hline Antibiotic & 12.52 & 0.00040 & I & 9.61 & 0.00193 & Meningitis & 14.24 & 0.00016 \\
\hline Medic & 10.88 & 0.00097 & Always & 9.08 & 0.00258 & Symptom & 14.23 & 0.00016 \\
\hline To orient & 9.95 & 0.00160 & Team & 8.89 & 0.00286 & Viral & 13.31 & 0.00026 \\
\hline Continuous & 9.95 & 0.00160 & Disease & 8.89 & 0.00287 & Membrane & 13.31 & 0.00026 \\
\hline Environment & 9.95 & 0.00160 & Permanent & 8.65 & 0.00326 & To present & 11.8 & 0.00059 \\
\hline Puncture & 9.95 & 0.00160 & To catch & 8.65 & 0.00326 & Brain & 11.57 & 0.00066 \\
\hline Medicine & 9.95 & 0.00160 & Death & 8.65 & 0.00326 & Leg & 9.86 & 0.00168 \\
\hline Lumbar & 9.95 & 0.00160 & Majority & 8.65 & 0.00326 & Meningeal & 8.17 & 0.00426 \\
\hline To observe & 8.84 & 0.00295 & Experience & 8.65 & 0.00326 & Jet & 8.17 & 0.00426 \\
\hline Exam & 7.58 & 0.00590 & Contamination & 8.65 & 0.00326 & Cervical & 8.17 & 0.00426 \\
\hline To use & 7.42 & 0.00645 & Service & 8.65 & 0.00326 & Brudzinski & 8.17 & 0.00426 \\
\hline Epi & 7.42 & 0.00645 & & & & Powder & 6.49 & 0.01082 \\
\hline To utilize & 7.42 & 0.00645 & & & & Irritation & 6.49 & 0.01082 \\
\hline To promote & 7.42 & 0.00645 & & & & Traumatic & 6.49 & 0.01082 \\
\hline Tomography & 7.42 & 0.00645 & & & & & & \\
\hline
\end{tabular}

Source: Dendrogram obtained via DHC’s IRAMUTEQ. Sobral/CE, 2018

Figure 1. Dendrogram of the words presented in classes, obtained from the descendent hierarchical classification (DHC). Sobral, Ceará, Brazil, 2018

“(...) the nursing needs to quicken the skull's tomography and laboratory exams, such as the lumbar puncture (...)" (E7)

"The urgency diagnostic is only possible with specific image and laboratory exams." (E1)

"We also live, in emergency, the skull's tomography accomplishment, the neurosurgery evaluation, and the lumbar puncture collection (...)." (E8)

Another observed aspect of the speeches related to the nursing interventions was the emphasis given by the participants concerning the recurrent use of IPE (Individual Protection equipment) for the prevention of infectious diseases.

"I use the mask N95, bonnet, apron, that are all used in the hospital's daily routine." (E6).

"We mainly use the mask N95." (E7).

"We use the cap, mask, mask N95 in cases that we need to have a continuous contact with the client, gloves, when we are going to accomplish procedures." (E8)

"Uso contínuo de máscara bico de pato no paciente, nos acompanhantes e nos profissionais." (TE6)

"We Always use the mask N95, disposable coat, and every time we touch the patient, subsequently, we wash our hands." (TE8)

Regarding the context of nursing care, the nursing professionals' speeches pointed out that the interviewed recognizes 
and expresses, in their daily routine, actions guided toward the nursing care's humanization.

“(...) we offer comfort, to both, patient and companion, since the patients feel embarrassed for being isolated. They need emotional support." (E2)

"To provide comfort to the client, even inside an isolation environment" (E8)

"I look out, so the patient does not feel excluded or mistreated due to the isolation." (E4)

"To isolate and orient the patient, if they are conscient, and their relatives, and keep the sigil for the patient's safety." (TE9)

\subsection{Class II: Feelings associated to the care of patients with meningitis}

In the second class, that is equal to $32.1 \%$ of the textual corpus, were approached the nursing professionals' feelings when dealing with patients afflicted with meningitis in the emergency sector.

The speeches showed that the nursing team possess feelings of fear/concern, related to the risk of respiratory contamination by meningitis. Such feelings are associated, by the participants, to the disease's gravity and the susceptibility and exposition that the professionals that works in the emergency sector goes through. Moreover, the speeches highlighted the worries in becoming fomite in the cross contamination of relatives.

"I am afraid of getting the disease and transmit it to my relatives." (TE2).

"My fear is to bring the bacteria to my relatives." (E2).

"I am always afraid of getting infected." (E4).

"Every time that I go to a patient with meningitis, I have the knowledge, i correctly use the IPE's, but I am always afraid of the contamination and the disease's gravity." (E10).

"My fear is that after the contact, because I can get the disease and pass it to someone." (TE9).

Another feeling that was highlighted in the professionals' speeches was the insecurity. The nursing team reported that they do not feel prepared to act with patients afflicted by meningitis since there was an absence of previous training. The demand and interest for training was highlighted in the participants' speeches: the nursing team recognizes that the permanent training/education are options that contribute to the acquisition of more safety, by the professionals.

"I do not feel completely ready, due to the concern with my safety." (E3).
"I do not feel safe, I would like to have educative moments, with discussion of cases and a higher interaction with the team." (E4).

"The only reason that I do not have more safety is because I never had any training." (TE6).

"I perceive the need to be updated about the issue via permanent education in the service." (E5).

"We do not have capacitation, only the empiric experience, but we had no training, that is the reason I do not feel safe." (TE7).

\subsection{Class III: Alert signs for the diagnostic of meningitis during the emergency care}

In this class, which corresponds to $38.7 \%$ of the corpus, the professionals reported to know the definition of meningitis and the signs and symptoms that they should be aware, for being classic characteristics of the grievance. In addition to this, the participants' speeches brought the types of meningitis that were more attended in service.

“The meninges' inflammation may cause chills, fever, pain in the muscles or in the neck, nausea, vomits, headache, neck stiffness and tachypnea." (E1).

"Meningitis is the inflammation of the meninges. The symptoms are fever, vomit, neck stiffness and intense headache." (E3).

"Meningitis is a communicable disease, usually presented in the following forms: viral, bacterial and, in some cases, post-traumatic. They had frequent headaches." (TE9).

"Meningitis happens when the brain's membranes inflame. The patient arrives showing high fever, headache, vomit, disorientation, and diminishing of the conscience level." (E9).

"Meningitis is an inflammation motivated by three possible vectors: bacterial, viral and fungal. The patient has an intense headache, with a focus on the occipital and the hardening of the cervical region with vomit and fever." (E11).

From the speeches, it is possible to point out that some professionals have the knowledge concerning the disease's main signs and symptoms, such as intense headache, incoercible vomit, nape stiffness and fever, in addition to other, such as mental confusion and coma, which demonstrates that the patients experience these pathologies in their daily routine.

\section{Discussion}

Regarding the nurses' profile that acts in the emergency, the predominance of males among them was verified. The high- 
est number of men, among the emergency nurses, may have a relation to the job's specificity, but also may indicate a change in the gender in the profile of the nursing workforce.

A study made in the South of Brazil showed that nursing still is a predominantly female profession, but there is a growth in the number of men. The percentage of male nurses has tripled from 1970 to 2011 , going from $2.7 \%$ to $9.6 \% .^{[14]}$

In hospital services to the urgency and emergency care, the nurse's acting involves essential specificities and articulation to the management of the care to patients with complex needs that require a scientific improvement, technological handling, and extensive humanization to the relatives due to the unexpected impact of a situation that puts their beloved one at risk. This way, accordingly with the exploratory study made in Northeast of Brazil, there is a need to improve the nurses' knowledge with emphasis on the accomplishment of specializations in the field. ${ }^{[16]}$

The infectious diseases are relevant to public health since they are easy to disseminate and, consequently, show high rates of outbreaks. This way, it is necessary that health professionals, when facing these pathologies, take adequate precautions to prevent the fast dissemination.

The infections of the central nervous system (CNS) as meningitis, represents a group of diseases caused by infectious agents. All types of known pathogens may cause infections in different levels of the CNS. The clinical suspicion and the early beginning of the treatment are decisive for these process' prognostic. ${ }^{[17]}$

The experience of the nursing team has shown itself permeated by the realization of the patient's isolation, in the emergency sector. One observes, by the participant's speeches, that the team intensifies the client's care to maintain their safety after the admission in the service. Under a study made in Canada, the handling of infectious disease, that demands isolation, have been frequent in the nurses' daily routine. ${ }^{[18]}$ Such facts highlight the importance of the preparation in both, theoretical and practical field, for the nursing professionals, concerning the patient's isolation, as well as the need for a hospital structure that enables the intervention, that goes through the safety of the patient and occupational.

The administration of medication was the most present procedure in the nursing team's speeches. This finding converges with the one found in a study made in the South of Brazil whose results show that the administration of medication is continuous in the nursing routine and that the number of hours directed to this activity impacts the workload of these professionals. ${ }^{[19]}$

Published by Sciedu Press
In this context, it is observed that the administration of medication is an attribution of the nursing team and that, in cases of meningitis in the emergency sector, it is relevant, because the intravenous pharmacological therapy has as purpose, not only to ease the symptoms or to bring more comfort to the patient, but also to indicate the pharmacological dose to attack the pathogen causing the inflammatory process of the meninges. Therefore, the administration of medication's presence in patients with meningitis, in the nursing team's experience, points out to the pertinence of scientific evidence concerning this procedure, in the emergency department and its impact on the nursing workload.

The interviewed professionals' speeches highlight the nursing contribution to the accomplishment of laboratory and image exams. The implementation of quick methods for meningitis' diagnostic is an important requirement for health services, in the seek to quickly provide the results for the multi-professional team and to provide a better assistance for the patients. ${ }^{[20]}$ Meningitis is a pathology where the quick diagnostic, followed by an effective therapy, impacts the patient's survival and reduction of injuries. This highlights the relevance to develop a method that promotes an accurate diagnostic of the disease.

A study made with patients attended in a hospital's emergency department of Pakistan showed that, normally, the clinical history and the exam have low diagnostic accuracy when used alone. In meningitis' case, the final diagnostic's burden is the cerebrospinal fluid exam and the bacterial isolation through culture, in clinically compatible cases. ${ }^{[21]}$ Therefore, it is pertinent that the nursing team has knowledge about the diagnostic method to intervene, organize the sector's logistic, provide material and contribute to the accomplishment of such exams.

Concerning the IPE's, the professionals understand the importance of their use even during laboratory activities, these equipment are indispensable for the health professionals, since they, constantly deal with patients afflicted with infect contagious diseases, in addition to the work environment that is favorable to infections.

The standard-precautions (SP) are measures proposed by the Center for Disease Control and Prevention (CDC) and must be universally adhered by all professionals that work in healthcare to decrease the contamination risks by biological agents and prevent infections related to the health care. ${ }^{[22]}$ In this regard, the adoption of precaution measures by the team in suspected or confirmed cases of meningitis is important, in a way that the infection chances inside the hospital are avoided. These measures can be done with the use of surgical masks for all professionals, as well as the patients' compan- 
ions, in addition to the standard precaution of hands washing, use of protection glasses during invasive procedures, bonnets and aprons in the first 24 hours of hospitalization.

After the speeches' analysis, it was observed that the team directs their attention not only to possible physical and biological injuries from the disease, but also the ones that contemplates the humanization of the care process. Such action is under the National Curricular Guidelines, whose trainee's profile, when leaving the institution, should be of a nurse with the following formation: generalist, humanist, critical and reflexive. The professional must be qualified for the nursing exercise based on the scientific and intellectual rigor and ruled by ethical principles, that consider the biopsychosocial dimensions and its determinants. ${ }^{[23]}$

To give care and actively hearing the patient and his relative is important to reduce de anxiety levels and assure a humanized and holistic nursing care. The humanized assistance favors the establishment of a therapeutic bond, which reflects in better communication about the understanding of the disease, its risks, complications and standard-precaution forms, which, in turn, ease the therapeutic adhesion and the contribution of the patient and his companion.

In the beginning of the XXI century, the Ministry of Health from Brazil launched the National Program Humanize Hospital Care (PNHAH) that culminated in the creation of the National Humanization Policy in 2003 (PNH) - HumanizaSUS - being a guiding axis for management and assistance practices, having as main foundation the participation and joint responsibility of the involved subjects in the several work process of health. Under the PNH, humanization involves different actors from the process to promote health use, workers and managers - guided by the following values: autonomy, protagonism, join responsibility, supportive bond and collective participation in the management process. ${ }^{[24,25]}$

PNH is a transversal public policy that deals with the work process in health as a whole, involving care and management, thus ensuring the protagonism of subjects and collectives, going through the offer of services, care technologies and the construction of safe, harmonious environment that can give comfort and wellbeing for the users. ${ }^{[23]}$

For that, it is needed to form professionals with the necessary skills to attend the demands required for the job. In urgency and emergency units these skills are: knowledge, skills and specific attitudes to offer an individualized care, that is worthy and humanized to whoever seeks this type of care and that, in humanization's case, includes reception, communication, dialog, problem-solving, respect, and knowing how to listen. ${ }^{[24]}$
Regarding the present feelings in the nursing professionals' experience, fear and unsafety were observed. From the speeches, one perceives that the team needs training/capacitation about the theme since all professionals are afraid of developing a disease in an occupational way and such fact may compromise the quality of the given care.

Accordingly with a study in Egypt, permanent education in nursing supports professional practice and the provision of safe and high-quality care for the patients. ${ }^{[26]}$ Such fact shows that health education and nursing training are relevant components to improve the professionals' feelings, decrease fear and unsafety, which, in turn, will subsidize to nursing the accomplishment of care with safety and efficiency.

The experiences of the study's participants enabled to relate theory and practice for the disease's clinical diagnostic, since in their speeches the pathology symptoms prevailed. Meningitis is characterized by the presence of fever, headache, nausea and/or vomit, changes in the conscience level and presence of meningeal signs. The classic triad of fever, changes in the conscience level and neck stiffness, many times, incompletely appears and is more frequent to find it complete in the pneumococcal meningitis. ${ }^{[17]}$

Some signs and symptoms are more frequent in infections caused by specific pathogens. Therefore, in infections caused by Listeria there is a higher tendency for the presence of seizures and focal deficits. Cutaneous manifestation such as cutaneous eruption or palpable crimson are more frequent in cases originated by Neisseria meningitidis. ${ }^{[17]}$ In the face of the importance of a quick recognition of meningitis' suggestive signs, it is pertinent that nursing knows which are those signs and how to identify them, so the emergency sector, may intervene in the treatment and assure the biosafety of the professionals and patients.

This study possesses its investigation as a limitation because it had as the research's scenario, a public hospital and contemplating only the nursing team. Therefore, its findings may diverge from what was found in private hospitals and from what could be found in a multi-professional health team.

The findings contribute to the state of the art referred to in the theme for unveiling subjective aspects in the nursing care to patients with meningitis, in emergency sectors. Moreover, it contemplates a theme that is remotely explored in nursing's scientific literature: Infect contagious diseases that prevails in the emergency sector.

\section{Conclusion}

The experience of the nursing team concerning care to patients with meningitis, attended in emergency departments, 
was shown as permeated by interventions (relative to the patient's isolation, administration of medication, contribution for the accomplishment of laboratory and image exams, use of IPE's and humanization); feelings (fear and unsafety, along with the demand for training) and knowledge about signs and symptoms to where the nursing should be aware, since the can suggest the infection by meningitis, with a consequent need of specific action.

\section{REFERENCES}

[1] Brasil. Ministério da Saúde. Secretaria de Vigilância em Saúde. Boletim epidemiológico: Meningite bacteriana não especificada no Brasil 2007-2016: desafio para a vigilância das meningites. Brasília. 2019; 50(3). Available from: https://portalarquivos2. saude.gov . br/images/pdf/2019/fevereiro/01/2018-038.pdf

[2] Flórez JAO, Navas MPG, Ochoa JWC, et al. Características clínicas y paraclínicas de niños con meningitis bacteriana aguda en el Hospital Universitario San Vicente Fundación en Medellín, Colombia. 2011-2015: estudio descriptivo-retrospectivo. Acta Neurol Colomb. 2017; 33(2): 84-93. https://doi.org/10.22379/24224022138

[3] Chen YR, et al. The effect of postoperative infection on survival in patients with glioblastoma. Journal of Neurosurgery. 2017; 127(4): 807811. PMid:27935360 https://doi.org/10.3171/2016.8. JNS 16836

[4] Sherrod BA, et al. Risk factors for unplanned readmission within 30 days after pediatric neurosurgery: a nationwide analysis of 9799 procedures from the American College of Surgeons National Surgical Quality Improvement Program. Journal of Neurosurgery Pediatric. 2016; 18(1): 350-362. PMid:27184348 https://doi.org/10.3 171/2016.2.PEDS15604

[5] Ceará. Governo do Estado do Ceará. Secretaria de Saúde. Boletim epidemiológico: Meningites. Fortaleza-CE, 2018. Available from: https://www. saude.ce.gov.br/wp-content/uploads /sites/9/2018/06/boletim_meningites_30_05_2018.pdf

[6] Zhang G, et al. Evaluation of a micro/nanofluidic chip platform for the high-throughput detection of bacteria and their antibiotic resistance genes in post-neurosurgical meningitis. International Journal of Infectious Diseases. 2018; 70(1): 115-120. PMid:29559366 https://doi:10.1016/j.ijid.2018.03.012

[7] Dias FCF, Rodrigues Junior CA, Cardoso CRL, et al. Meningite: aspectos epidemiológicos da doença na região Norte do Brasil. Revista de Patologia do Tocantins, 2017; 4(2): 46-49. https://doi: 10.20873/uft. 2446-6492.2017v4n2p46

[8] Bellicci Júnior JA, Matsuda LM. O enfermeiro no gerenciamento à qualidade em Serviço Hospitalar de Emergência: revisão integrativa da literatura. Rev Gaúcha Enferm. 2011; 32(4): 797806. PMid:22299284 https://doi.org/10.1590/S1983-144 72011000400022

[9] Sosa RG, et al. Approach to central nervous system infections in the emergency department. Clinical Pediatric Emergency Medicine. 2015; 16(1): 11-18. https://doi.org/10.1016/j.cpem. 2015. 01.005

[10] Gaieski DF, et al. Emergency Neurologic Life Support: Meningitis and Encephalitis. Neurocritical Care. 2017; 27(1): 124-133. PMid:28916998 https://doi.org/10.1007/s12028-017-045 5-y

Published by Sciedu Press
One highlights the importance of making other studies that enable the comparison between the findings in several contexts (public hospital X private hospital; other regions of Brazil) to allow a higher unveiling about the experience of nursing in the care of patients with meningitis, in the emergency sector and other sectors.

\section{CONFlicts OF InTEREST Disclosure}

The authors declare that there is no conflict of interest.
[11] Cardim MG, Santos AEV, Nascimento MAL, et al. Children in hospital isolation: relationship and experiences with nursing staff. $\mathrm{R}$ Enferm UERJ. 2008; 16(1): 32-8.

[12] Ling L, et al. Nursing Management of Lumbar Drainage in Cryptococcal Meningitis: A Case Report. Journal of Neuroscience Nursing 2017; 49(4): 198-202. PMid:28661942 https://doi.org/10.1 $097 / \mathrm{JNN} .0000000000000293$

[13] Nascimento LCN, Souza TV, Oliveira ICS, et al. Theoretical saturation in qualitative research: an experience report in interview with schoolchildren. Rev Bras Enferm. 2018; 71(1): 22833. PMid:29324967 https://doi.org/10.1590/0034-7167-2 016-0616

[14] Camargo BV, Justo AM. Tutorial para o uso do software de análise textual IRAMUTEQ. Laboratório de Psicologia Social da Comunicação e Cognição - LACCOS., Universidade Federal de Santa Catarina, 2013.

[15] LuchtemberN, Pires DEP. Nurses from the Mobile Emergency Service: profile and developed activities. Rev Bras Enferm. 2016; 69(2): 194-201.

[16] Dantas UIB, Silva RC, Cavalcanti AUA, et al. Otrabalho dos enfermeiros no setor de urgência: limites e perspectivas. Rev enferm UFPE on line. 2015; 9(Supl. 3): 7556-61.

[17] Bou BM, Soriano AS, Moreno MC, et al. Protocolo diagnóstico del paciente con sospecha de infección del sistema nervioso central. Tratamiento empírico. Medicine. 2015; 11(89): 5348-51. https: //doi.org/10.1016/j.med.2015.10.021

[18] Kaba A, Baumann A, Kolotylo C, et al. A descriptive case study of the changing nature of nurses' work: The impact of managing infectious diseases requiring isolation. American Journal of Infection Control. 2017; 45(2): 200-202. PMid:27776824 https: //doi.org/10.1016/j.ajic.2016.06.036

[19] Kreling A, Magalhães AMM. Administração de medicamentos carga de trabalho da equipe de enfermagem em unidade de internação clínica. Cogitare Enferm. 2018; 23(1): e50974. https : //doi.org/10.5380/ce.v23i1.50974

[20] Machado BC, Vieira HR, Alves MRM, et al. Avaliação do desempenho da PCR em tempo real para o diagnóstico de meningite por Enterovirus. Rev Inst Adolfo Lutz. 2016; 75.

[21] Nazir M, Wani WA, Malik MA, et al. Cerebrospinal fluid lactate: a differential biomarker for bacterial and viral meningitis in children. J Pediatr. 2018; 94(1): 88-92. PMid:28866321 https: //doi.org/10.1016/j.jped.2017.03.007

[22] Carvalho DC, Rocha JC, Gimenes MCA, et al. Acidentes de trabalho com material biológico na equipe de enfermagem de um hospital do Centro-Oeste brasileiro. Esc Anna Nery. 2018; 22(1): e20170140. 
[23] Riegel F, Crossetti MGO, Siqueira DS. Contributions of Jean Watson's theory to holistic critical thinking of nurses. Rev Bras Enferm. 2018; 71(4): 2072-2076. PMid:30156699 https ://doi.org/10.1 590/0034-7167-2017-0065

[24] Michelan VCA, Spiri WC. Perception of nursing workers humanization under intensive therapy. Rev Bras Enferm. 2018; 71(2): 372-8. PMid:29412296 https://doi.org/10.1590/0034-7167-2016-0485

[25] Sousa KHJF, Damasceno CKCS, Almeida CAPL, et al. Humaniza- ção nos serviços de urgência e emergência: contribuições para o cuidado de enfermagem. Rev Gaúcha Enferm. 2019; 40: e20180263. PMid:31188988 https://doi.org/10.1590/1983-1447.2019 .20180263

[26] Abdelmowla RAA, Sayed SY, Elmagd NSA. Lumbar Puncture: Nurses' Knowledge, Practice and Patients' Satisfaction with Nursing Care. American Journal of Nursing Science. 2017; 6(5): 433-439. https://doi.org/10.11648/j .ajns. 20170605.18 